\title{
The Evaluation of the Quality of Agricultural Economic Growth in China
}

\author{
Yanni LIU, Ming XU \\ Northwest University, Xi'an, China \\ $\{371157992,751538761\}$ @qq. com
}

\begin{abstract}
Based on the connotation of the agricultural economic growth, this paper objectively evaluates the sequence development level of agricultural economic growth quality and the regional differentiation characteristics in China from four dimensions of the agricultural production efficiency, agricultural economic structure, the farmers' quality of life and the sustainable development level, and put forward to promote the adjustment and optimization of agricultural economic structure, take the resource-saving and environmentfriendly sustainable development road, and improve the efficiency of agricultural production which is beneficial to the enhancement of the agricultural economic growth quality and the shift of the agricultural economic development mode.
\end{abstract}

Keywords: Agriculture, Growth Quality, Entropy Method.

\section{Introduction}

Agriculture is the basis of a country's economy and the foundation of a country's development. The agricultural problem has always been the focus of government and economists. Considering China, with the rapid development of economy and the continuous acceleration of urbanization and industrialization process, the transformation of the agricultural sector has been demanded.

We can see that over the past 30 years of reform and opening up, China's agriculture has achieved great success, providing sufficient sources of production factors for the rapid growth of the country's economy, and successfully feeding more than 20 percent of the world's population with less than 10 percent of the world's arable land. However, the rapid urbanization and industrialization of the transition period have caused a series of corresponding problems and a great impact on the agricultural sector. These problems can be systematically summarized as follows. First, the unit agricultural input is not proportional to output. Second, progress in agricultural technology has been slow. Third, agricultural sustainable development capacity is weak. Fourth, the quality of rural labor is not high enough. 


\section{$2 \quad$ Literature Overview}

In modern times, many western bourgeois thinkers such as Adam Smith, David Ricardo, Freidrich Liszt and other people held the one-sided view that the development of the society is merely a kind of economic phenomenon, and the development process is the process of the material wealth growth. However, with the deepening of people's understanding, Thomas and Barro found that economic development is not equivalent to economic growth $[1,10]$. Comparing with economic growth, economic development has broader contents, including the reform and improvement of social structure in terms of economy, politics, culture and law. As Liu broadly defined that improve the quality of economic growth refers to continuously improve the stability of the economic growth, the sustainability of economic growth mode, the coordination of economic growth structure and the harmony of the economic growth efficiency [7]. As Chao and Hui proposed that the extension of economic growth should be defined as the economic aspects that are closely related to economic growth, including four dimensions: the structure of economic growth, the stability of economic growth, the welfare change and the fruits distribution of economic growth, the utilization of resources and the cost of ecological environment [2].

In fact, agricultural economic growth is the growth of quantity rather than quality. In order to fundamentally realize the transformation of the quantity of agricultural economic growth to quality, we must recognize the connotation of agricultural economic growth quality.

Based on the connotation of the quality of agricultural economic growth, this paper evaluates the quality of agricultural economic growth in China. The scholars above are mainly based on the perspective of the whole national economy to study the quality of China's economic growth, but rarely discuss the quality of agricultural economic growth. Actually, we should pay more attention to the quality of agricultural growth and the transformation of agricultural development mode while focusing on the "three rural issues "(agriculture, rural areas and farmers).

\section{Methods}

\subsection{The construction of evaluation index system of China's agricultural economic growth quality}

The quality of agricultural economic growth is the quality of economic growth during the agricultural economic growth period. The concept of agricultural economic growth quality is based on the meaning of economic development. Its content is not only limited to the improvement of the utilization efficiency of resources, labor, capital and other production factors, but should also include the optimization of the economic structure, the promotion of the quality of farmers' life, the sustainable development of ecological environment and a series of content related to the development of agriculture, rural areas and farmers. The quality of agricultural 
economic growth is the development and supplement of agricultural growth mode. Therefore, when establishing the index system, we should cover all aspects of agricultural development as much as possible to establish a complete, systematic and comprehensive index system. Building an index system of assessment of agricultural economic growth quality is helpful to understand the process of agricultural development, the impetus, and resistance of agricultural economic growth and the direction of the agricultural economic growth.

Taking the connotation of agricultural economic growth quality as a starting point, following the purpose, scientific, systematic, feasibility, comparability and pertinence principles, on the basis of previous research results, this study chooses 26 comprehensive indicators which can reflect the intention and level of the quality of agricultural economic growth as the indicator elements of the study. The 26 indicators elements are not completely irrelevant, but at a certain level of abstraction to reflect the different aspects of the agricultural economic growth quality. In this paper, 26 index elements are systematically classified to establish the evaluation dimension of agricultural economic growth, namely, the dimension of agricultural production efficiency, the dimension of the agricultural economic structure, the dimension of farmers' life quality and the dimension of sustainable development.

Based on the above principle and previous research, and combining the requirements of the agricultural economic development status, we set up an evaluation indicator system of agricultural economic growth quality (see Table 1).

Table 1. The evaluation index system of China's agricultural economic growth quality.

\begin{tabular}{|c|c|c|c|c|}
\hline First grade indexes & Order & $\begin{array}{l}\text { Second-grade } \\
\text { indexes }\end{array}$ & Unit & Index nature \\
\hline \multirow{10}{*}{$\begin{array}{l}\text { Agricultural production } \\
\text { efficiency }\end{array}$} & 1 & Agricultural GDP & 100million yuan & positive \\
\hline & 2 & $\begin{array}{l}\text { Farmers per capita net } \\
\text { income }\end{array}$ & $\begin{array}{l}\text { Yuan/100 hundred } \\
\text { people }\end{array}$ & positive \\
\hline & 3 & $\begin{array}{l}\text { Agricultural labor } \\
\text { productivity }\end{array}$ & $\begin{array}{l}\text { 100million yuan/100 } \\
\text { hundred people }\end{array}$ & positive \\
\hline & 4 & $\begin{array}{l}\text { Agricultural land } \\
\text { productivity }\end{array}$ & $\mathrm{Kg} / \mathrm{ha}$ & positive \\
\hline & 5 & $\begin{array}{l}\text { Per capita grain } \\
\text { production }\end{array}$ & $\begin{array}{l}100 \text { hundred tons } / 100 \\
\text { hundred people }\end{array}$ & positive \\
\hline & 6 & TFP growth rate & $\%$ & positive \\
\hline & 7 & $\begin{array}{l}\text { Industrial structure } \\
\text { adjustment capability } \\
\text { index }\end{array}$ & $\%$ & positive \\
\hline & 8 & $\begin{array}{l}\text { Per capita water } \\
\text { resources }\end{array}$ & $\begin{array}{l}\text { 100million cubic } \\
\text { meters/100hundred } \\
\text { people }\end{array}$ & positive \\
\hline & 9 & $\begin{array}{l}\text { Unit sown area } \\
\text { production value }\end{array}$ & $\begin{array}{l}\text { 100million } \\
\text { yuan/thousand }\end{array}$ & positive \\
\hline & 10 & $\begin{array}{l}\text { Unit area machinery } \\
\text { total power }\end{array}$ & $\begin{array}{l}\text { 100hundred } \\
\mathrm{kW} / \text { thousand hectares }\end{array}$ & positive \\
\hline
\end{tabular}




\begin{tabular}{|c|c|c|c|c|}
\hline & 11 & $\begin{array}{l}\text { Per capita electricity } \\
\text { consumption }\end{array}$ & $\begin{array}{l}\text { 100hundred } \\
\text { kw/100hundred }\end{array}$ & positive \\
\hline \multirow[t]{5}{*}{$\begin{array}{l}\text { Agricultural economic } \\
\text { structure }\end{array}$} & 12 & $\begin{array}{l}\text { Effective irrigation } \\
\text { rate }\end{array}$ & $\%$ & positive \\
\hline & 13 & $\begin{array}{l}\text { Acres of arable land } \\
\text { water resources }\end{array}$ & $\begin{array}{l}\text { 100million cubic } \\
\text { meters/thousand } \\
\text { hectares }\end{array}$ & positive \\
\hline & 14 & $\begin{array}{l}\text { Rural minimum } \\
\text { subsistence allowance }\end{array}$ & 100hundred yuan & positive \\
\hline & 15 & Urbanization rate & $\%$ & positive \\
\hline & 16 & Engel coefficient & $\%$ & positive \\
\hline \multirow[t]{7}{*}{$\begin{array}{l}\text { Famers' quality } \\
\text { of life }\end{array}$} & 17 & $\begin{array}{l}\text { Per hundred people } \\
\text { above junior high } \\
\text { school }\end{array}$ & $\%$ & positive \\
\hline & 18 & $\begin{array}{l}\text { Rural employment } \\
\text { rate }\end{array}$ & $\%$ & positive \\
\hline & 19 & $\begin{array}{l}\text { Illiteracy and semi- } \\
\text { illiteracy rate }\end{array}$ & $\%$ & negative \\
\hline & 20 & $\begin{array}{l}\text { Chemical fertilizer } \\
\text { usage }\end{array}$ & $\begin{array}{l}\text { 100hundred } \\
\text { tons/thousand hectares }\end{array}$ & negative \\
\hline & 21 & Pesticide usage & Tons/thousand & negative \\
\hline & 22 & Disaster rate & $\%$ & negative \\
\hline & 23 & Forest cover & $\%$ & positive \\
\hline \multirow[t]{3}{*}{ Sustainable development } & 24 & $\begin{array}{l}\text { Soil erosion control } \\
\text { area }\end{array}$ & Thousand hectares & positive \\
\hline & 25 & Health personnel & Person & positive \\
\hline & 26 & $\begin{array}{l}\text { Percentage of } \\
\text { investment in science } \\
\text { and technology } \\
\text { education }\end{array}$ & $\%$ & positive \\
\hline
\end{tabular}

\subsection{The determination of evaluation method of China's agricultural economic growth quality}

After establishing the evaluation index system for the transformation of agricultural development mode, we should first determine the weight of each index. At present, the method of determining index weight is divided into two categories: subjective weight assignment and objective weight assignment. The subjective weight assignment mainly includes Delphi method, analytic hierarchy process and so on. The objective weight assignment method mainly contains factor analysis method, entropy method, optimal sequence diagram method and variation coefficient method. This paper adopts the entropy method.

Entropy method is mainly used to determine the weight by obtaining information entropy of each index. If the information entropy is smaller, the degree of disorder of information is lower, the index variance is bigger, the more information is transmitted, and the more weight is given to the index. On the other hand, if the information entropy is greater, the degree of disorder of information is higher, the 
index variance is smaller, the less information is transmitted, the less weight is assigned to the index. Information entropy is an objective description of the degree of divergence between indicators, and it does not add any man-made factors. Therefore, the results are objective, authentic and scientific by using information entropy to determine the weight of the index and to evaluate the transformation of agricultural development mode.

In order to evaluate the level of agricultural economic growth quality of $m$ year in a certain area, the evaluation index system has $n$ indexes, and establishes mathematical model: The domain is $U=\left\{u_{1}, u_{2}, \ldots, u_{m}\right\}$, each sample consists of data representation of $m$ indicators, namely $u_{i}=\left\{X_{i 1}, X_{i 2}, \ldots X_{i m}\right\}$, and can get the original data matrix of the evaluation system $X=\left(x_{i j}\right)_{m \times n}$, the data standardization matrix is $B=\left\{b_{i j}\right\}_{m \times n}$, The larger the gap between index value $x_{i j}$, the more important the index is in the comprehensive evaluation. The information entropy value of $x_{j}$ is $e_{j}=-k \sum_{i=1}^{m} b_{i j} \ln b_{i j}$ the constant $k$ in the formula is related to the sample number $m$ of the system. If the index value is all equal, then the index will not function in the comprehensive evaluation, the higher the order degree of a system, the greater the information entropy, conversely, the lower the information entropy. Therefore, we can calculate the weights of each index according to the difference degree of each index value and the tool of information entropy, providing the basis for multiple indexes comprehensive evaluation.

For a system with a complete disorder of information, $e=1$; When the m-sample is in a completely disordered state of distribution, $b_{i j}=1 / m, k=1 / \ln m$, $0 \leq e \leq 1$. The information utility value of the index of the item $j$ is determined by the difference between the information entropy $e_{j}$ and 1. By using the entropy value method to estimate the weights of each index, the essence is to calculate the value coefficient of the index information, the higher the value coefficient, the greater the importance to the evaluation, the weight of index of the item $j$ is $w_{j}=d_{j} / \sum_{j=1}^{m} d_{j}$.

For the evaluation of the sample, it is possible to use the product $f_{i j}$ of the weight $w_{j}$ of item-j index and the evaluation index proximity $x_{i j}^{\prime}$ of item-j of sample-i in the standard matrix as the evaluation value of, namely $f_{i j}=w_{j} x_{i j}^{\prime}$, The evaluation value of sample-i is $f_{i}=\sum_{j=1}^{m} f_{i j}$.

For the evaluation system of the multilayer structure, according to the additive of information entropy, using the index information utility value of the lower structure, the weight $W_{j}$ corresponding to the upper structure is determined according to the proportion. The utility value of each index of the lower structure is summed up, the sum $D_{k}$ of utility value of different kinds of indexes, is obtained, and then the sum of 
utility values of all indexes. The weight of the corresponding subsystems of $W_{k}=D_{k} / D$, the weight of the index corresponding to the upper structure is $W_{j}=d_{j} / D$, therefore, the evaluation value of the index corresponding to the upper structure is: $f_{i j}^{\prime}=\sum_{i=1}^{n} W_{j} x_{i j}^{\prime}$, if a high level contains $k$ points, then the evaluation value of the upper structure: $F=\sum_{i=1}^{k} \sum_{j=1}^{n} W_{j} p_{i j}$.

\subsection{The steps of comprehensive evaluation by entropy method}

Firstly, process the value of each index dimensionless. Convert each index value $x_{i j}$ into a relative number $x_{i j}^{\prime}$ without units, while the numerical specification is within [0, 1]. In this analysis, the dimensionless method of sampling linear type is: for the positive index (the larger the better index), $x_{i j}^{\prime}=\frac{x_{i j}-\min \left(x_{j}\right)}{\max \left(x_{j}\right)-\min \left(x_{j}\right)}$; for the reverse index (the smaller the better index), $x_{i j}^{\prime}=\frac{\max \left(x_{j}\right)-x_{i j}}{\max \left(x_{j}\right)-\min \left(x_{j}\right)}$.

Secondly, the coordinate translation and normalization of dimensionless data. In order to eliminate the effect of the normalized logarithmic calculation, coordinate translation for $x_{i j}^{\prime}$, the formula is: $b_{i j}=x_{i j}^{\prime}+A$, A is the translation amplitude, $A>\min \left(x_{i j}^{\prime}\right)$. The closer the value of $A$ is to $\min \left(x_{i j}^{\prime}\right)$, the more significant the evaluation result is $(\mathrm{A}=0.01)$. After the coordinate translation normalized the data according to the calculation formula is: $p_{i j}=b_{i j} / \sum_{i=1}^{m} b_{i j}$, and the normalized matrix $P=\left(p_{i j}\right)_{m \times n}$ is obtained.

Finally, calculate the entropy value $e_{j}$ and redundancy of the index $d_{j}$. Among them: $e_{j}=-k \sum_{i=1}^{m} p_{i j} \ln p_{i j}, k=1 / \ln n ; d_{j}=1-e_{j}, \quad$ measured the difference between the indexes, the smaller the entropy value $e_{j}$ is, the larger the differential coefficient $d_{j}$ is, the more important the indexes are. On this basis, calculate the 
weight $w_{j}=d_{j} / \sum_{i=1}^{n} d_{j}$ and further can get the comprehensive evaluation score of agricultural economic growth quality in the $i$ year $F_{i}=\sum_{j=1}^{n}\left(w_{j} \times p_{i j}\right)$.

\section{Results}

\subsection{Analysis of the evaluation index system of China's agricultural economic growth quality}

Based on the formula of entropy method above, the regional disparity of the quality of agricultural economic growth in China from 2000 to 2012 was calculated to evaluate the regional distribution of agricultural economic growth quality.

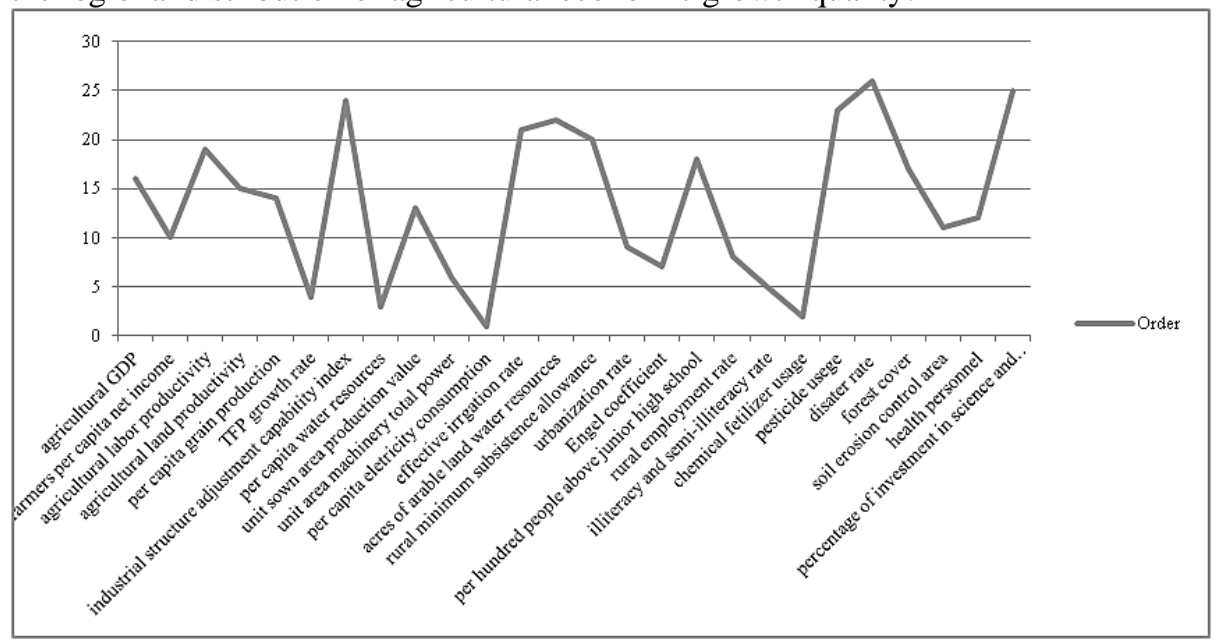

Fig. 1. The weight of each evaluation index of China's agricultural economic growth quality.

Using entropy method, we can obtain the weight of 26 indexes according to the collected data (see Chyba! Nenalezen zdroj odkazů.). Most of the data of this article from "China Statistical Yearbook", "China Compendium of Statistics 1949-2008", etc., some information can be directly obtained by the data, and some of the data which cannot be directly acquired is obtained by simple calculation and transformation.

From the perspective of the evaluation index weight of China's agricultural economic growth quality in Fig. 1, the weights of per capita electricity consumption, fertilizer application rate, per capita water resources, TFP growth rate, illiteracy and semi-illiteracy rate, etc., were higher. It means the above indexes have an important influence on the quality of agricultural economic growth. On the whole, the four aspects of agricultural production efficiency, agricultural economic structure, farmers' 
life quality and sustainable development of China's agricultural economic growth is not negligible importance, anyone will affect the quality of China's agricultural economic growth.

\subsection{The comprehensive evaluation of agricultural economic growth quality of different regions in China}

According to the weight of each index in the evaluation system of the process of China's agricultural economic growth quality, the comprehensive scores of each subsystem and the quality of agricultural economic growth are calculated, and the results are shown in Tab. 2.

Table 2. The comprehensive evaluation of China's agricultural economic growth quality.

\begin{tabular}{|c|c|c|c|c|c|c|c|c|c|c|}
\hline \multirow[t]{2}{*}{ District } & \multicolumn{2}{|c|}{$\begin{array}{l}\text { Agricultural } \\
\text { production } \\
\text { efficiency }\end{array}$} & \multicolumn{2}{|c|}{$\begin{array}{l}\text { Agricultural } \\
\text { economic } \\
\text { structure }\end{array}$} & \multicolumn{2}{|c|}{$\begin{array}{l}\text { Farmers' quality } \\
\text { of life }\end{array}$} & \multicolumn{2}{|c|}{$\begin{array}{l}\text { Sustainable } \\
\text { development }\end{array}$} & \multicolumn{2}{|c|}{$\begin{array}{l}\text { Weighted total } \\
\text { factor }\end{array}$} \\
\hline & Score & Order & Score & Order & Score & Order & Score & Order & Score & Order \\
\hline Beijing & 0.14497 & 1 & 0.11186 & 4 & 0.12467 & 6 & 0.06716 & 28 & 0.44866 & 3 \\
\hline Tianjin & 0.12787 & 3 & 0.115 & 3 & 0.08844 & 29 & 0.06231 & 29 & 0.39362 & 8 \\
\hline Hebei & 0.09319 & 11 & 0.07603 & 8 & 0.12199 & 7 & 0.11101 & 12 & 0.4022 & 6 \\
\hline Shanxi & 0.05362 & 19 & 0.02922 & 19 & 0.1014 & 21 & 0.12933 & 7 & 0.31357 & 20 \\
\hline Inner & 0.0426 & 23 & 0.01796 & 26 & 0.10193 & 20 & 0.15169 & 1 & 0.31418 & 19 \\
\hline Liaoning & 0.09837 & 9 & 0.05732 & 11 & 0.09509 & 25 & 0.12577 & 9 & 0.37654 & 9 \\
\hline Jilin & 0.09389 & 10 & 0.01842 & 25 & 0.09073 & 27 & 0.12523 & 10 & 0.32826 & 13 \\
\hline Heilong & 0.06034 & 18 & 0.00546 & 31 & 0.10031 & 22 & 0.14281 & 3 & 0.30892 & 21 \\
\hline Shanghai & 0.13944 & 2 & 0.16968 & 1 & 0.09071 & 28 & 0.04933 & 30 & 0.44916 & 2 \\
\hline Jiangsu & 0.12446 & 4 & 0.09011 & 6 & 0.12119 & 9 & 0.06981 & 27 & 0.40556 & 5 \\
\hline Zhejiang & 0.10755 & 6 & 0.1114 & 5 & 0.13763 & 1 & 0.10263 & 15 & 0.45922 & 1 \\
\hline Anhui & 0.04033 & 27 & 0.03078 & 17 & 0.12478 & 5 & 0.09464 & 21 & 0.29053 & 24 \\
\hline Fujian & 0.10402 & 7 & 0.06536 & 10 & 0.10643 & 17 & 0.04023 & 31 & 0.31603 & 18 \\
\hline Jiangxi & 0.04371 & 22 & 0.0307 & 18 & 0.09856 & 24 & 0.11172 & 11 & 0.28469 & 26 \\
\hline Shandong & 0.11454 & 5 & 0.07113 & 9 & 0.12675 & 3 & 0.09457 & 22 & 0.40698 & 4 \\
\hline Henan & 0.06921 & 14 & 0.04276 & 12 & 0.1335 & 2 & 0.09386 & 23 & 0.33933 & 12 \\
\hline Hubei & 0.08034 & 12 & 0.0257 & 20 & 0.09404 & 26 & 0.09552 & 20 & 0.29559 & 23 \\
\hline Hunan & 0.07752 & 13 & 0.03626 & 16 & 0.10254 & 18 & 0.10235 & 16 & 0.31867 & 15 \\
\hline Guangdong & 0.06505 & 16 & 0.08279 & 7 & 0.11054 & 15 & 0.08514 & 25 & 0.34352 & 11 \\
\hline Guangxi & 0.04042 & 26 & 0.02309 & 23 & 0.10244 & 19 & 0.09684 & 19 & 0.2628 & 29 \\
\hline Hainan & 0.09929 & 8 & 0.03817 & 14 & 0.07436 & 31 & 0.0719 & 26 & 0.28371 & 27 \\
\hline Chongqing & 0.03308 & 29 & 0.01623 & 28 & 0.09924 & 23 & 0.10127 & 17 & 0.24982 & 31 \\
\hline Sichuan & 0.04127 & 25 & 0.01905 & 24 & 0.10891 & 16 & 0.14856 & 2 & 0.31779 & 16 \\
\hline
\end{tabular}




\begin{tabular}{lllllllllll} 
Guizhou & 0.00661 & 31 & 0.006 & 30 & 0.11752 & 11 & 0.12684 & 8 & 0.25695 & 30 \\
Yunnan & 0.04219 & 24 & 0.01613 & 29 & 0.11668 & 12 & 0.13378 & 6 & 0.30879 & 22 \\
Tibet & 0.00732 & 30 & 0.15961 & 2 & 0.11835 & 10 & 0.11082 & 13 & 0.39611 & 7 \\
Shaanxi & 0.06734 & 15 & 0.02319 & 22 & 0.12516 & 4 & 0.13998 & 5 & 0.35567 & 10 \\
Gansu & 0.03572 & 28 & 0.01685 & 27 & 0.12163 & 8 & 0.14217 & 4 & 0.31636 & 17 \\
Qinghai & 0.05226 & 20 & 0.04213 & 13 & 0.11508 & 13 & 0.11035 & 14 & 0.31982 & 14 \\
Ningxia & 0.05117 & 21 & 0.02321 & 21 & 0.1144 & 14 & 0.09788 & 18 & 0.28665 & 25 \\
Xinjiang & 0.06264 & 17 & 0.03694 & 15 & 0.08192 & 30 & 0.09347 & 24 & 0.27497 & 28 \\
\hline
\end{tabular}

We found that China's agricultural economic growth quality differences between provinces from Tab. 3, the comprehensive score of agricultural economic growth quality factor of the national 31 provinces (autonomous regions and municipalities) are between $0.249819 \sim 0.459216$ in the 12 years from 2000 to 2012 . The main characteristic is the eastern provinces, especially the southeast coastal areas, have the highest quality of agricultural economic growth, the second in the central region and the lowest in the western region. Among them, the eastern region accounted for 9 of the 11 provinces with high-quality factors for agricultural economic growth, and 2 in the west. The central provinces accounted for 6 of the 10 provinces that at the middle level, 3 in the west and 1 in the east. Of the 10 provinces with lower scores, 5 were in the west, 4 in the central and 1 in the east.

The four subsystems of agricultural production efficiency, agricultural economic structure, the farmers' quality of life, agricultural sustainable development all have different degrees of contribution to China's agricultural economic growth quality. Moreover, the farmers' quality of life and sustainable agricultural development are the main factors that affect the quality of agricultural economic growth process, and achieved remarkable results. Farmers' life quality subsystem contributed $32.29 \%$ of the increase in the 12 years, and the agricultural sustainable development subsystem contributed $30.97 \%$ of the increased score., this shows that from 2000 to 2012 with the development of the economy, China has made great progress in per capita electricity consumption, fertilizer application rate, per capita water resources, TFP growth rate, illiteracy and semi-illiteracy rate, per unit area agricultural machinery total power, Engel's coefficient and rural employment rate. The agricultural production efficiency subsystem contributed $21.29 \%$ of the increase in score, while the agricultural economic structure subsystem contributed $15.43 \%$ of that. The contribution of the agricultural economic structure subsystem is less than the weight of its own, which indicates that the change of agricultural economic structure lags behind economic development. In addition, the contribution of agricultural production efficiency subsystem is less than its weight as well, which proves that the agricultural development in the 12 years is extensive and not sustainable. The rural developed at the cost of resource consumption and environmental pollution, and only achieved the growth of agricultural output, but not the corresponding economic development and social progress, resulting from the less attention being paid on the elevation of the living standards of rural residents. 


\section{Conclusion}

For one thing, innovating the technological level of agricultural production and improving the technical efficiency. This includes three aspects, first of all, to increase innovation and development of new technologies. We should speed up the construction of a modern agricultural technology system, vigorously train scientific and technological leaders, deepen the Production-Study-Research cooperation, and improve the development of agricultural science and technology. Besides, we should vigorously develop diversified, socialized agro-technology, popularize the service organizations and farmers' cooperative organizations, regularly conduct professional training and cultivate practical talents on the labor force in the countryside. Secondly, strengthen the contact between scientific research institutions and agricultural production personnel, so that the research of agricultural science and technology can be applied to agricultural production to a greater extent, and promote the development of actual productivity of agriculture. To deepen reform of rural science and technology system, increase the investment in agricultural scientific research, increase subsidies for farmers using agricultural technology, encourage scientific research institutions and technical personnel at all levels to increase the research and development for the agricultural products market, and promote the construction of folk scientific research organizations. Thirdly, perfect the agricultural technology promotion system. We should strengthen the promotion of advanced practical agricultural technologies, focusing on the promotion of good varieties, water-saving irrigation, formula fertilization, integrated pest control, crop cultivation and management. Besides, we should establish the novel diversified system of agricultural technology promotion, strengthen the public welfare function of agro-technical extension service, promote the agricultural sci-tech household project comprehensively, foster the agricultural science and technology demonstration household and enhance their ability of radiation-driven. We should strengthen the construction of agricultural sci-tech service platform, perfect the network of the agricultural sci-tech trade market and accelerate the transformation of sci-tech achievements.

For the other thing, improve the quality of agricultural labor force. Attaching importance to the education and cultivation of the quality and competence of the rural labor force, we should pay attention to the following aspects: first, we should continue to increase the investment in rural education, pay attention to the education in rural and backward areas, realize the improvement of rural education in Shaanxi province, and improve the education age and level of the agricultural population. Second, improve the efficiency of investment in education. We should increase the input of basic education in rural areas and improve the effectiveness and efficiency of the investment; we should strengthen the cultivation of the students majoring in agriculture and forestry, and encourage them to join in the actual production and operation. Third, we should pay attention to the training of farmers ' professional skills, and make them change from experience-based to knowledge-based, from go-italone to an organizational type, from an identity style to a professional style. 
Acknowledgements. This work was supported by National Social Science Fund (Grant No 15BJL057) and Education Department of Shaanxi Provincial Government Fund (Grant No 14JK1701).

\section{References}

1. Barro, R. J.: Quantity and Quality of Economic Growth, http://www.bcentral.cl/documents/20143/32019/bcch_archivo_167977_es.pdf/4c7c013e090d-6777-debf-3e1f1a74e613, last accessed 2017/12/05.

2. Chao X., Hui K.: Measuring quality of economic growth of China. The Journal of Quantitative and Technical Economics 2009(6), 75-86 (2009), DOI: 10.13653/j.cnki.jqte.2009.06.008

3. Eshima, N., Tabata, M. Three predictive power measures for generalized linear models: The entropy coefficient of determination, the entropy correlation coefficient and the regression correlation coefficient. Computational Statistics \& Data Analysis. 55(11), 3049-3058 (2011). DOI: 10.1016/j.csda.2011.05.018.

4. Guo Z., Zeng F.: Construction and empirical analysis of evaluation index system of agricultural development mode transformation: A case study of Hunan province. Rural Economy and Science-Technology 22(7), 101-104 (2011).

5. He J.: Evaluation system for the transformation of agricultural economic growth mode. Commercial Research 2009(10), 135-137 (2009), DOI: 10.13902/j.cnki.syyj.2009.10.019.

6. Li L., Zhang Y.: The construction of evaluation index system and primary assessment of the transformation of China's economic development pattern. China Industrial Economics 2011(4), 54-63 (2011).

7. Liu S.: Discussion on the sound and fast development. Journal of Economic Research 2007(6), 4-13 (2007).

8. Safar, M. H., Sorkhoh, I. Y., Farahat, H. M., Mahdi, K. A.: On Maximizing the Entropy of Complex Networks. In: Shakshuki, E, Younas, M. (eds.) Procedia Computer Science, vol. 5, pp. 480-488, Niagara Falls, Ontario (2011).

9. Su J., Shen W.: A preliminary study on improving entropy method. Jiangsu Commercial Forum 2007(26), 188-188 (2007), DOI: 10.14097/j.cnki.5392/2007.26.005.

10. Thomas, V., Dailimi, M., Dhareshwar, A., Kaufmann, D., Kishor, N., Lopez, R., Yan W.: The quality of growth. 1st edn. The World Bank, Washington, D.C. (2000).

11. Zhang C.: Overview of the research on the transformation of agricultural development mode. Economic Review 304(3), 121-124 (2011), DOI: 10.16528/j.cnki.221054/f.2011.03.016. 